\title{
SEMIOTIKA PIERCE DALAM RAHASIA CINTA DAN RESONANSI INDONESIA KARYA AHMADUN YOSI HERFANDA
}

\author{
Idawati $^{1 \text {, }}$, Edo Frandika ${ }^{2)}$, Saleh Fahrudin ${ }^{3)}$ \\ ${ }^{123}$ FKIP, Universitas Muhammadiyah Lampung \\ Pos-el: idawati473@gmail.com, efrandika@yahoo.com
}

\begin{abstract}
Abstrak
Penelitian memiliki tujuan untuk mengungkapkan makna dari puisi Ahmadun Yosi Herfanda yang berjudul Rahasia Cinta dan Resonansi Indonesia. Peneliti menggunakan Semiotika Pierce untuk mengkaji kedua puisi tersebut. Dalam kajian Semiotika Pierce fokus dalam kajiannya meliputi ikon, indeks, dan simbol. Pemilihan puisi Rahasia Cinta dan Resonansi Indonesia untuk dikaji dalam penelitian ini karena dari puisi Rahasia Cinta dan Resonansi Indonesia menggunakan pemilihan majas dan makna kiasan yang menarik dan menggunakan pilihan majas yang penuh dengan arti, sehingga kedua puisi tersebut sangat cocok untuk dikaji menggunakan kajian Semiotika Pierce. Dari hasil penelitian yang telah dilakukan, didapatkan tiga unsur Semiotika Pierce dalam kedua puisi tersebut. Ketiga unsur tersebut ialah ikon, indeks, dan simbol. Unsur Semiotika Pierce Pada puisi Rahasia Cinta yang paling dominan ialah ikon sedangkan indeks dan simbol terdapat satu. Dalam puisi Resonansi sama-sama menemukan dua analisis dalam ikon, indeks, dan simbol.
\end{abstract}

Kata kunci: semiotika pierce, puisi, rahasia cinta, resonansi Indonesia

\begin{abstract}
The aim of this research is to reveal the meaning of Ahmadun Yosi Herfanda's poem, entitled Secrets of Indonesian Love and Resonance. The researcher uses Pierce's Semiotics to study the two poems. In the study of Semiotics, Pierce's focus in his study includes icons, indexes, and symbols. The selection of the Indonesian Secret of Love and Resonance poetry to be studied in this study is because the Indonesian Secret of Love and Resonance poetry uses an interesting selection of figurative language and figurative meanings and uses a choice of figurative language that is full of meaning, so that the two poems are very suitable to be studied using Pierce's Semiotics study. From the results of the research that has been done, three elements of Pierce's Semiotics are found in the two poems. The three elements are icons, indexes, and symbols. Elements of Pierce's Semiotics in the poem Secret of Love, the most dominant is the icon, while the index and symbol are one. In Resonance poetry both find two analyzes in icon, index, and symbol.

Keywords: Pierce's semiotics, poetry, secret of love, Indonesian resonance
\end{abstract}




\section{PENDAHULUAN}

Karya sastra identik kaitannya dengan karya seni yang rekat akan kehidupan manusia. Terry Eagleton (2010: 4) berpendapat bahwa sastra termasuk ke dalam karya tulis yang menampilkan keindahan serta bentuk bahasanya yang dipadatkan, diputarbalikan dan diatur sedemikian rupa sehingga memunculkan keindahan.

Perkembangan zaman tidak dapat mempengaruhi eksistensi karya sastra dalam masyarakat, hal ini terbukti dari banyaknya karya sastra yang hadir di dalam masyarakat. Karya sastra memiliki bermacam-macam jenis, puisi juga termasuk ke dalam karya sastra. Puisi bagian dari karya sastra terdiri dari tulisan-tulisan indah yang dikarang atau disusun sedemikian rupa sehingga tulisan tersebut menjadi karangan yang indah dan juga penuh makna tersirat dalam tulisan tersebut. Menurut Heman Waluyo (2002: 1), karya sastra terdiri atas pilihan kata yang dipadatkan dan rima yang sesuai dengan bunyi jika dibaca menjadi padu dengan kata-kata terpilih bersifat imajinatif.

Seiring perkembangan zaman banyak dijumpai penyair-penyair terkenal di Indonesia salah satunya ialah Ahmadun
Yosi Herfanda. Beliau merupakan ketua komite sastra DKJ pada tahun 2010. Banyak karya-karyanya yang telah dipublikasikan dari nasional hingga internasional. Seperti buku Sang Matahari, Sajak Penari, dan Fragmenfragmen Kekalahan.

Puisi dapat dikaji menggunakan bermacam-macam kajian. Puisi Rahasia Cinta dan Resonasi Indonesia karya Ahmadun Yosi Herfanda dalam penelitian ini dikaji menggunakan Semiotika Pierce karena peneliti hendak mengungkapkan ikon, indeks, dan simbol yang ada dalam puisi tersebut. Menurut peneliti puisi tersebut sangat cocok untuk dikaji menggunakan Semiotika Pierce. Pierce terkenal dengan trikotominya dalam semiotik. Trikonomi yang dijabarkan oleh Pierce meliputi ikon, indeks, dan simbol.

Penelitian sebelumnya yang menggunakan Semiotika Pierce ialah penelitian Isnaini (2017) yang berjudul "Analisis Semiotika Sajak Tuan Karya Sapardi Djoko Damono" penelitian tersebut fokus pada aspek tanda-tanda sedangkan dalam penelitian ini fokus pada indeks, simbol, dan ikon. Bahan kajian yang dikaji berbeda, penelitian yang dilakukan Isnaini menggunakan puisi Sapardi Djoko Damono sedangkan 
dalam penelitian ini menggunakan puisi karya Ahmadun Yosi Herfanda.

\section{METODE PENELITIAN}

Objek material dalam penelitian ini merupakan Puisi Rahasia Cinta dan Resonansi Indonesia karya Ahmadun Yosi Herfanda. Objek formalnya ialah semiotika pierce peneliti dalam penelitian ini bertujuan untuk memahami makna (Indeks, ikon, dan simbol) yang terkandung dalam Puisi Rahasia Cinta dan Resonansi Indonesia karya Ahmadun Yosi Herfanda

Bait-bait puisi Rahasia Cinta dan Resonansi Indonesia karya Ahmadun Yosi Herfanda merupakan sumber data dalam penelitian ini. Metode dan pengumpulan data menggunakan metode studi pustaka agar hasil yang didapat sesuai dengan harapan peneliti. Metode pustaka menurut Faruk (2012: 56) merupakan metode yang dilakukan dengan cara mencari dan menemukan semua sumber data yang terkait dengan objek yang akan diteliti. Dalam menanalisis data yang ditemukan peneliti menggunakan metode deskriptif untuk memaparkan hasil temuan dalam puisi yang akan dikaji.

\section{HASIL DAN PEMBAHASAN}

Hasil dan pembahasan puisi Rahasia Cinta dan Resonansi Indonesia karya Ahmadun Yosi Herfanda menggunakan pendekatan semiotika pierce mengenai indeks, ikon, dan simbol sebagai berikut.

\section{Rahasia Cinta}

Rahasia cinta ada pada bunga yang tak pernah ingkar

Memekarkan dirinya demi кири-кири

Yang membutuhkan madu untuk menitikkan serbuk sari

Pada benih hingga tumbuh buah ranum bagi kehidupan

Rahasia cinta ada pada kesetiaan pantai yang selalu Sabar menunggu kecupan ombak, dan atas kesabarannya Ombak selalu bergairah memberikan kecupan pada Bibir sang pantai, hingga tak ada detik yang terlewatkan

Dari kasih sayangnya.

Rahasia cinta ada pada gairah kesetiaan

Yang selalu mempertemukan dua hati yang saling 
Merindu untuk bersua dan menyatukan nafas

Dalam kehidupan yang penuh makna

Rahasai cinta ada pada semua yang bersedia menyayangi

Tanpa terhitung bakal mendapat apa setelah memberi

Rahasia cinta ada pada hati yang terbuka untuk menerima

Bagai samodra ikhlas menerima tiap gelisah muara, Menghidupi berjuta nelayan dan memeramkan resah Berjuta nahkoda yang selalu merindu dermaga

Rahasia cinta ada pada hati Yang selalu bersedia berbagi

Dari luka hingga nikmat paling sejati

Rahasia cinta ada di dalam dada

Yang tulus menjadi samodra maaf

Dengan lautan pengertian

Bagi yang satu dengan lainnya

Kota Tua, 2010

\section{Resonansi Indonesia}

Bahagia saat kau kirim rindu Termanis dari lembut hatimu Jarak yang memisahkan kita Laut yang mengasuh hidup nahkoda

Pulau-pulau yang menumbuhkan kita

Permata zamrud di khatulistiwa:

Kau dan aku

Berjuta tubuh satu jiwa

Kau semaikan benih-benih kasih Tertanam dari manis cintamu Tumbuh subur di ladang tropika Pohon pun berbuah apel dan semangka

Kita petik Bersama bagi rasa bersaudara:

Kau dan aku

Berjuta kata satu jiwa

Kau dan aku

Siapakah kau dan aku?

Jawa, cina, batak, arab, dayak

Sunda, madura, ambon, atau papua?

$A h$, tanya itu tak penting lagi bagi kita:

Kau dan aku

Berjuta wajah satu jiwa 
Idawati, Edo Frandika, Saleh Fahrudin...

Ya, apalah artinya jarak pemisah

kita

Apalah artinya Rahim ibu yang

berbeda?

Jiwaku dan jiwamu, jiwa kita

Tulus menyatu dalam

genggaman burung garuda

Jakarta, 1984/1999.

\section{Ikon}

Ikon dapat diartikan sebagai hubungan penanda dan petanda yang bersifat alamiah atau mirip. Pradopo (2013: 120) ikon bersifat alamiah atau tidak dibuat-buat antar penanda dengan petandanya. Ikon memiliki kemiripan dalam antara rupa dengan rujukannya. Menurut pandangan Pierce (Santoso, 1993: 10) fungsi ikon sebagai penanda bentuk objeknya. Ikon menjelaskan secara jelas maksud dan tujuan dari objeknya, seperti kesamaan antara gambar dan aslinya. Dalam sajak Rahasia Cinta, ikon didapatkan pada bait pertama baris pertama dan kedua.

Rahasia cinta ada pada bunga yang tak pernah ingkar.

Dalam bait tersebut memiliki tanda bahwa bunga yang tak pernah ingkar sebagai bentuk dari cinta yang sesungguhnya, bunga sebagai ikon cinta dalam kehidupan manusia. Ikon juga terdapat pada bait terakhir dalam puisi Rahasia Cinta,

\section{Rahasia cinta ada pada hati}

Dapat kita kaji bahwa dalam kehidupan masyarakat, hati sering digambarkan sebagai ikon cinta. Ketika seseorang sedang jatuh cinta akan memberikan gambar hati kepada pasangannya, hal ini menjelaskan bahwa hati menjadi ikon bagi cinta tersebut.

Selanjutnya dalam puisi Resonansi Indonesia terdapat beberapa ikon yang ditemukan oleh peneliti. Seperti dalam bait kedua pada baris ke lima.

Kita petik Bersama bagi rasa bersaudara:

Dalam bait tersebut menjelaskan tentang persaudaraan yang saling berbagi rasa suka dan duka. Kita dalam bait tersebut termasuk ke dalam ikon atau penanda aku dan kamu, yang menjelaskan bahwa meskipun mereka berbeda suku, Bahasa dan darah selama menjadi warga negara Indonesia mereka semua bersaudara. Hal ini juga terdapat dalam bait ketiga baris ketiga

Jawa, cina, batak, arab, Dayak

Sunda, madura, ambon, atau papua?

Dapat kita pahami dalam bait tersebut bahwa suku yang berbeda bukan sebagai alasan bagi kita untuk tidak menjadi saudara. Ini menunjukkan bahwa 
kami dalam bait tersebut sebagai ikon masyarakat Indonesia yang penuh akan perbedaan tetapi dengan perbedaan tersebut bukan menjadi alasan bagi kita untuk tidak saling menghargai karena kita bersaudara sebangsa dan setanah air.

\section{Indeks}

Indeks dapat kita artikan ialah hubungan kedekatan yang memiliki sebab akibat. Hal ini sejalan dengan pemahaman Pradopo (2013:120) bahwa indek itu sebab-akibat antara penanda dengan petandanya itulah indeks (Santoso, 1993: 11) indeks itu fungsinya sebagai penanda yang memberikan isyarat bagi petandanya. Contohnya tersenyum sebagai tanda Bahagia, menangis sebagai tanda sedih.

Dalam puisi Rahasia Cinta, dan Resonansi Indonesia ditemukan beberapa indeks, seperti pada puisi Rarahasia Cinta bait kedua yaitu,

Rahasia cinta ada pada kesetiaan pantai yang selalu Sabar menunggu kecupan ombak, dan atas kesebarannya Ombak selalu bergairah memberikan kecupan pada Bibir sang pantai, hingga tak ada detik yang terlewatkan

Dari kasih sayangnya.
Dalam bait tersebut dapat kita pahami terjadinya sebab akibat antara penanda dengan petandanya (Indeks) seperti banyak yang disampaikan oleh para Ustaz, sabar merupakan puncak dari keiklasan, sabar akan menjadikan pribadi yang lebih baik dan mendapatkan hasil yang baik pula. Sama dengan pada bait puisi di atas, menjelaskan bahwa kesabaran yang dia tunjukan untuk menunggu memberikan hasil dari kesabarannya yaitu kasih sayang dari orang yang dia cintai. Ini menjelaskan sebab akibat, jika kita bersabar maka akan mendapatkan hasil dari kesebaran yang telah kita lalui.

Indeks juga terdapat dalam puisi Resonansi Indonesia pada bait pertama baris kesatu dan kedua

\section{Bahagia saat kau kirim ridu}

Termanis dari lembut hatimu

Pada bait tersebut dapat dipahami bahwa terjadi hubungan antara penanda dan petanda berupa sebab-akibat. Penanda dalam bait tersebut ialah kirim rindu dan petandanya ialah bahagia. Penyair mengungkapkan kebahagiannya karena mendapatkan kabar rindu. Ini menunjukkan sebab akibat yang terjadi dalam bait tersebut. Selanjutnya indeks terdapat pada bait ke dua

Kau semaikan benih-benih kasih Tertanam dari manis cintamu 
Idawati, Edo Frandika, Saleh Fahrudin...

Tumbuh subur di ladang tropika

Pohon pun berbuah apel dan semangka

Kita petik Bersama bagi rasa bersaudara:

Dari bait tersebut menunjukkan sebab akibat yang terjadi, hasil dari usaha yang telah dia lakukan membuahkan hasil untuk mempererat hubungan antara mereka. Ini menunjukkan bahwa adanya sebab akibat yang telah dilakukan.

\section{Simbol}

Simbol diartikan sebagai bentuk perumpamaan yang telah sering digunakan oleh masyarakat. Simbol sebagai tanda yang telah disepakati bersama. Pierce (Santoso, 1993: 11) menjelaskan bahwa simbol memiliki fungsi sebagai penanda yang telah sering digunakan oleh masyarakat. Sama dengan pendapat yang telah diutarakan oleh Pradopo (2013: 120) bahwa tanda itu bersifat suka-suka atau arbiter dan tidak ada hubungannya antara penanda dan petanda. Misalnya orang tua (perempuan) di dalam masyarakat ada yang menyebutnya ibu, bunda, mami, mom, dll. Hal tersebut menunjukkan simbol sebagai tanda yang bersifat suka-suka namun lazim digunakan.

Di dalam puisi Rahasia Cinta dan Resonansi Indonesia ditemukan beberapa simbol. Seperti dalam puisi Rahasia Cinta pada bait ke lima berikut

Rahasia cinta ada pada hati yang terbuka untuk menerima Bagai samodra ikhlas menerima tiap gelisah muara, Menghidupi berjuta nelayan dan memeramkan resah Berjuta nahkoda yang selalu merindu dermaga

Bait tersebut menggambarkan bahwa rahasia cinta ialah hati yang dapat menerima segalanya. Simbol dalam bait tersebut ialah Samudra, Samudra digambarkan oleh masyarakat sebagai bentangan lautan yang sangat besar. Sesuai dengan bait tersebut bahwa untuk dapat menjalin cinta harus memiliki hati yang ikhlas seperti Samudra yang luas yang dapat menerima dan juga dapat menghidupi para nelayan. Pada puisi Resonansi Indonesia juga ditemukan beberapa simbol, yakni pada bait ke satu pada baris ke empat sebagai berikut

\section{Laut yang mangasuh hidup nahkoda}

Bait tersebut menjelaskan bahwa nahkoda hidup dari luat yang ada. Nahkoda dan laut sebagai simbol dalam masyarakat Indonesia yang lekat kaitannya dengan kehidupam para nelayan. Nahkoda merupakan profesi seorang yang hidup mengarungi lautan 
untuk mencari nafkah. Pada bait terkahir dalam puisi Resonansi Indonesia juga terdapat simbol, yakni,

Jiwaku dan jiwamu, jiwa kita

Tulus menyatu dalam

genggaman burung garuda

Bait tersebut menjelaskan bahwa masyarakat Indonesia hidup berdasarkan simbol burung garuda yang berjiwa besar, bertanah air satu, bersaudara sebangsa dan setanah air meskipun di dalam masyarakat terdiri dari berbagai macam bahasa, suku, budaya dan agama.

\section{SIMPULAN}

Penelitian yang dilakukan dengan menggunakan semiotika pierce dalam puisi Rahasia Cinta dan Resonansi Indonesia karya Ahmadun Yosi Herfanda didapatkan bahwa dalam kedua puisi tersebut memiliki unsur semiotika pierce, yakni indek, simbol, dan ikon. Pada puisi Rahasia Cinta yang paling dominan ialah ikon sedangkan indeks dan simbol terdapat satu. Dalam puisi Resonansi sama-sama menemukan dua analisis dalam ikon, indeks, dan simbol.

Dalam sajak Rahasia Cinta, ikon didapatkan pada bait pertama baris pertama dan kedua Ikon juga terdapat pada bait terakhir dalam puisi Rahasia Cinta.
Dalam puisi Resonansi Indonesia terdapat beberapa ikon yang ditemukan oleh peneliti. Seperti dalam bait kedua pada baris ke lima. Hal ini juga terdapat dalam bait ketiga baris ketiga. Indeks pada puisi Rahasia Cinta bait kedua. Indeks juga terdapat dalam puisi Resonansi Indonesia pada bait pertama baris kesatu dan kedua Selanjutnya indeks terdapat pada bait ke dua. Simbol dalam puisi Rahasia Cinta pada bait ke lima. Pada puisi Resonansi Indonesia juga ditemukan beberapa simbol, yakni pada bait ke satu pada baris ke empat, sementara pada bait terakhir dalam puisi Resonansi Indonesia juga terdapat simbol.

\section{DAFTAR PUSTAKA}

Eagleton, Terry. (2010). Teori Sastra: Sebuah Pengantar Komprehensif. (Edisi Terjemahan Harfiah Widyawati dan Evy Setyarini). Yogyakarta: Jalasutra.

Faruk. (2012). Metode Penelitian Sastra. Yogyakarta: Pustaka Pelajar. Faruk. 1996. "Aku" dalam Semiotika Riffaterre, Semiotika Riffaterre dalam "Aku". Humaniora, Vol. 3, hlm. 24-33. Mahsun. (2005). Metode penelitian bahasa: tahapan strategi, metode, dan tekniknya. Jakarta: Rajagrafindo Persadar.

Pradopo, R. D. (2013). Pengkajian Puisi. Yogyakarta: Gadjah Mada University Press. 
Idawati, Edo Frandika, Saleh Fahrudin...

Santosa, P. (1993). Ancangan Semiotika dan Pengkajian Sastra. Bandung: Angkasa.

Waluyo, Herman J. (2002). Apresiasi Puisi. Jakarta: Gramedia.

Zubair, Charris dkk. (2010). Nyanyian Kebangkitan. Yogyakarta: Pustaka Pelajar. 